Meta

Journal des traducteurs

Translators' Journal

\title{
An Annotation to Shakespeare
}

\section{Augusta Caimmi}

Volume 19, numéro 3, septembre 1974

URI : https://id.erudit.org/iderudit/002187ar

DOI : https://doi.org/10.7202/002187ar

Aller au sommaire du numéro

Éditeur(s)

Les Presses de l'Université de Montréal

ISSN

0026-0452 (imprimé)

1492-1421 (numérique)

Découvrir la revue

Citer cet article

Caimmi, A. (1974). An Annotation to Shakespeare. Meta, 19(3), 138-140.

https://doi.org/10.7202/002187ar

Ce document est protégé par la loi sur le droit d'auteur. L'utilisation des services d'Érudit (y compris la reproduction) est assujettie à sa politique d'utilisation que vous pouvez consulter en ligne.

https://apropos.erudit.org/fr/usagers/politique-dutilisation/
Cet article est diffusé et préservé par Érudit.

Érudit est un consortium interuniversitaire sans but lucratif composé de l'Université de Montréal, l'Université Laval et l'Université du Québec à Montréal. Il a pour mission la promotion et la valorisation de la recherche. https://www.erudit.org/fr/ 


\section{An Annotation to Shakespeare}

Rarely can a translation disclose the author's intention to an audience more completely and more immediately than the original text would. Yet such is the case of two Shakespearian lines when read in their Italian translation :

1 . «... la nostra scena vi offrirà per due ore »;

"... is now the two hours" traffic of our stage ${ }^{1} \gg$;

2. «... in due brevi ore vedranno quanto li ripagherà ampiamente dello scellino speso $\gg ;$

«... away their shillings richly in two short hours ${ }^{2} »$.

An English reader, or better, an English audience, might find that Shakespeare's account of the performance time of Romeo and Juliet and Henry VIII is wanting in precision. An Italian audience would not.

It is a fact that in other Shakespearian lines some expressions cannot be taken literally :

《Tis a word or two of commendations sent from... ${ }^{3} 》$

"Please you deliberate a day or two ${ }^{4}$ "

"My business is a word or two with Claudio ${ }^{5}$ ».

It is obvious to the English audience that the words of commendations will be several, that the days $a$ few, and the word or two with Claudio, a short or long talk depending on the circumstances. These expressions indicate an indeterminate quantity, or length of time, which is not beyond reason in a given context, and is therefore within the boundaries of common sense or tradition.

1. The Tragedy of Romeo and Juliet, Prologue, line 12, in : The Complete Works of William Shakespeare, New York, Garden City Publishing Company, Inc., p. 315.

2. The Famous History of the Life of King Henry VIII, Prologue, line 13, in : op. cit., p. 1329.

3. The Two Gentlemen of Verona, act I, scene III, line 52, in : op. cit., p. 253.

4. The Two Gentlemen of Verona, act I, scene III, line 73, in : op. cit., p. 253.

5. Measure for Measure, act $\Pi$, scene I, line 20, in : op. cit., p. 907. 
More likely in Italian one would find simply two instead of one or two. And even when in English it is not possible to use the expression one or two, but only a few or several, in Italian is found two in a varied number of cases, indicating an extensive use of two with a sense of plurality. I believe that it is necessary to illustrate the above statement with a number of examples to clarify what could not be otherwise explained.

a. Ti cuocio due fagiolini : literally, «I cook you two beans»; meaning, «I cook you a certain amount of beans 》 i.e. "a normal serving of beans ».

b. Mangio due fragoline e basta : literally, «I eat two small strawberries only »; meaning, «I'll have some strawberries only ».

c. Mi piacerebbe mangiare due pasterelle : literally, «I would like to eat two small pastries $»$. This means, as many as a weight watcher off her diet should not have, and a no longer slim lady on a diet believes she can afford without getting any fatter! The word two lends itself easily to interpretation, and the relative implications depend not only on the context in which it is used but on the person who speaks it as well.

d. Andiamo a fare due passi : literally, "Let us go for two steps 》; meaning, «Let us go for a short or long walk», depending of how well one feels and on the condition of the weather.

e. Ritorno tra due ore : literally, «I'll be back in two hours, i.e. " a few hours $»$ or «several hours », depending on the latitude where this sentence is spoken (Milan, Rome, Naples). And if torno tra due ore is voiced by a husband at 1:00 p.m. on a sunny Saturday afternoon, he will be back home at 5:00 p.m., or 6:00 p.m., or even 10:00 p.m., supper time in Naples ! Yet this will not surprise an Italian wife! (As a parenthetic observation it is well known fact that if a tourist asks : "How far is the station?», inevitably the answer will be : "Very close, two hundred yards» (molto vicino, duecento metri). Better watch out and get a cab!)

Yet : due uova al burro will always be two fried eggs.

After having heard that Romeo and Juliet will last two hours, an English audience will wonder at the third hour. And probably a Shakespearian scholar might argue about the deliberate imprecision of Shakespeare; and justifiably so, since the Stratford theatre never performed the play in less than three hours and a half.

Romeo and Juliet and Henry VIII are plays of 2964 lines and 21 scenes, and of 2804 lines and 16 scenes, respectively. Even a reading is less than probable and they were meant to be performed.

That Shakespeare had a time misconception, or that two stands for rhyme requirements is possible but less than probable. In those days, might the scholar argue, theatrical performances took place in the open air, owing to the weather... Shakespeare wanted to reassure people that they would enjoyed the end ! Besides, their ears were impatient ${ }^{b}$. Some Philistine trends were already at work : was alienation an implication of the two hours?

6. The Tragedy of Romeo and Juliet, Prologue, line 13, in : op. cit., p. 315. 
That Shakespeare must have known Italian is by now generally agreed upon by scholars, and that Shakespeare very probably travelled to Italy is a thesis which has found a number of supporters. As Paul Stapfer says « Some critics think that Shakespeare had travelled to Italy $\gg .$. Karl Elze wrote a dissertation on the subject and "the conclusion arrived at by the author is that Shakespeare did travel in Italy.... ${ }^{7}$

I believe that it is therefore possible to propose that his use of two in the Prologues of Romeo and Juliet and Henry VIII is one indication that he not only knew Italian, but that he was even so familiar with it that he was able to make a distinction between serving two beans, two eggs, two hours.

Augusta Carmmi

7. P. Stapfer, Shakespeare and Classical Antiquity, New York, Burt Franklin, 1800, reprinted 1970, p. 128. 